\title{
Maluliyet Hesaplamalarında Karşılaşılan Sorunlar
}

\author{
Challenges in Measuring of Disability
}

\author{
Prof. Dr. Ahmet Hilal \\ Çukurova Üniversitesi Tıp Fakültesi, Adli Tıp Anabilim Dalı, Adana
}

Adli tıp uygulamaları içinde önemli bir yer tutan maluliyet hesaplamalarında ciddi sorunlar yaşandığı bilinmektedir. Son y1llara kadar bu konuda yapılan çalışmalar çok az iken son 2-3 yılda yayınlarda bir artış olduğu görülmektedir. Bunun nedeni olarak da bu konuda artan başvuru sayılarının yanında bu alanda olan eksikliklerin paylaşılması olarak da görülebilir.

Maluliyet (TDK sözlügünde); sakatlık olarak belirtilmektedir. Maluliyet kökeni Arapça olan bir kelime olduğu, sağlam olmayan hastalık ve sakatlık anlamına gelen illet sözcüğünden türemiş olduğu bildirilmektedir (1).

Türkiye Cumhuriyeti Anayasasının 5. Maddesinde Devletin görevlerini sayarken "sosyal hukuk devleti" olduğunu belirtir (2). Sosyal devlet olmanın gereği olarak ülkemizde trafik kazaları, iş kazaları sonrası veya bir başkasının eylemi sonucu vücut fonksiyonlarını kaybedenler/kaybettiğini iddia edenler ceza davaları dışında, tazminat talepleri için mahkemeler üzerinden ya da sigorta şirketleriyle anlaşma çabalarından dolayı, bireysel başvuruları ile Adli Tıp Anabilim dallarından veya Adli Tip uzmanlarından maluliyet oranlarının (meslekte kazanma gücünden kayıp oranlarının) hesaplanmasını talep etmektedirler.

Tazminat davalarına konu olan başvuruların büyük çoğunluğunun trafik kazaları sonrası sakat kalımlarında ya da sakat kalma iddialında olduğu görülmektedir. Emniyet Genel Müdürlüğü verilerine göre; Ülkemiz karayolu ağında 2014 yılında toplam 1.199 .010 adet trafik kazası meydana geldi. Bu kazalarda 3.524 ölüm, 285.059 yaralanma olduğu belirtilmektedir (3). Sayının bu kadar yüksek olması başvuru rakamlarını da arttırmaktadır.

Sigorta şirketleri mağdurlardan temel olarak 16 Aralık 2010 tarih ve 27787 sayılı resmi gazetede yayınlanan "Özürlülük Ölçütü, Sınıflandırması Ve Özürlülere Verilecek Sağlık Raporları Hakkında Yönetmelik" göre hesaplama yapılmasını isterken, Mahkemeler ve Yarg1- tay kararlarında ise 11 Ekim 2008 tarh ve 27021 sayılı resmi gazetede yayımlanan "Çalışma Gücü Ve Meslekte Kazanma Gücü Kaybı Oranı Tespit Yönetmeliği” göre hesaplanmasını istemektedir. Ayrıca daha az bilinmekte olan toplu taşımaya bağlı yaralanmalarda mahkemeler tarafindan 25 Mart 2004 tarihli "Karayolu Yolcu Taşımacılığı Zorunlu Koltuk Ferdi Kaza Sigortası Genel Şartları A.3.2. Sakatlık Teminatı" bölümüne göre de hesaplama yapılması istenmektedir. Aynı lezyona (sakatlığa) bu yönetmeliklerde farklı yüzdeler çıkabileceği gibi yönetmeliklerde bu lezyonların bulunmamasına da sıklıkla karşılaşılmaktadır.

Yukarıda bahsedilen yönetmeliklerden Özürlülük Ölçütü, Sınıflandırması Ve Özürlülere Verilecek Sağlık Raporları Hakkında Yönetmeliğin 1 maddesinde yönetmeliğin amacını "Bu Yönetmelik; özürlü sağllk kurulu raporlarının alınışı, geçerliliği, değerlendirilmesi ve özürlü sağllk kurulu raporu verebilecek yetkili sağlık kurumlartnın tespiti ile ilgili usul ve esasları belirlemek; özürlülerle ilgili derecelendirmelere, siniflandırmalara ve tanımlamalara gereksinim duyulan alanlarda ortak bir uygulama geliştirmek ve uluslararası sinıflandırma ve ölçütlerin kullanımının yaygınlaştırılmasını sağlamak amacıyla hazırlanmıştır." olarak belirtilmektedir (4). Çalışma Gücü Ve Meslekte Kazanma Gücü Kaybı Oranı Tespit Yönetmeliğinin amacı "Bu Yönetmeliğin amacl, 5510 sayll Sosyal Sigortalar ve Genel Sağlık Sigortası Kanununa göre sigortalı sayllanlar ve bunların bakmakla yükümlü oldukları veya hak sahibi çocuklarının çalışma gücü veya meslekte kazanma gücü kayıp oranlarının tespitine ilişkin usul ve esasları düzenlemektir." diye belirtilmektedir (5). Karayolu Yolcu Taşımacılığı Zorunlu Koltuk Ferdi Kaza Sigortası Genel Şartları sigorta konusunda "Bu sigorta, yurtiçi ve uluslararası yolcu taşımacılı̆̆ kapsamında seyahat eden yolcuları, sürücüleri ve yardımcılarını, taşımacılık hizmetinin başlangıcından bitimine kadar ge- 
çen seyahat süresi içinde, duraklamalar da dahil olmak üzere, maruz kalacakları her türlü kazaların neticelerine karşı aşă̆ıdaki şartlar çerçevesinde teminat altına alır." denmektedir (6). Bu yönetmeliklere bakıldığında sadece 3. yönetmeliğin trafik kazaları için çıkarıldığı görülmektedir. Ancak bu üç yönetmelik içinde en yetersiz olan ve sadece temel kayıpları içeren üçüncü yönetmeliktir.

Kişide saptanan lezyon kalıcılık kazandıktan sonra Mahkeme tarafından istenen yönetmeliğe göre (çok büyük oranda Çalışma Gücü Ve Meslekte Kazanma Gücü Kaybı Oranı Tespit Yönetmeliğine) hesaplama yapılmaktadır. Bununla birlikte yönetmelikte olmayan veya yönetmelikte tam karşılığı olmayan lezyonlar için sıklıkla "takdir" hakkı/yetkisi kullanılmaktadır. İlgili yönetmelikte böyle bir yetkinin nerede ve nasıl kullanılacağ memiştir. Ancak bu raporu düzenleyen Adli Tıp uzmanlarının hemen hemen tümü hakkaniyet (ya da vicdanlarını rahatlatmak) açısından takdir hakkını kullanmaktadır. Şöyle örnekleyebiliriz; humerus kırığı sonrası omuz eklem hareketlerinin normale göre yarısını kaybeden kişide yönetmelikte olan omuz eklem ankilozunun takdiren yarısını alarak hesaplama yapılmaktadır. Bu tamamen ilgili yönetmeliklerde ki yetersizlikten kaynaklanmış olmakla birlikte uygulamada farklı yerlerden aynı kişiye alınan raporlarda farklı sonuçlar çıkmasına neden olmaktadır. Adli Tıp uzmanları veya kurumlar raporlarında takdir hakkını kullanırken standart oluşturmak için kurallar koymakta ("içtihat" oluşturmakta) bundan başka kişi ve kurumların doğal olarak haberi bulunmamaktadır. $\mathrm{Bu}$ durumda ra- porlar arasında çelişkiye, mahkeme süreçlerinin uzamasına ve hak kayıplarına neden olmaktadır.

Özürlülük Ölçütü, Sınıflandırması Ve Özürlülere Verilecek Sağlık Raporları Hakkında Yönetmeliğin diğer yönetmeliklere göre daha ayrıntılı olmakla birlikte onun da eksiklikleri olduğu bir gerçektir. Özellikle tazminat davaları için önemli olan yaş ve mesleğin göz önüne alınmaması bu davalar için kullanılmasında ki en büyük handikaplardandir.

Olması gereken, özellikle maluliyetlerin hesaplanmasında kullanılacak ayrıntılı bir yönetmeliğin oluşturulmas1 gerekmektedir. Bu yönetmeliğin oluşunda çalışacak ekipte bu raporları en çok hazırlayan adli tıp uzmanlarının bakışının mutlaka yer alması gerekmektedir.

\section{Kaynaklar}

1. http://www.tdk.gov.tr/index.php?option=com b t s \& a r a m a $=\mathrm{k}$ e $1 \mathrm{i} \mathrm{m}$ e $\&$ g u i d $=$ T D K. GTS.574563079d48b0.03413638. (son erişim 25.05.2016)

2. https://www.tbmm.gov.tr/anayasa/anayasa_2011.pdf. (son erişim 25.05.2016)

3. http://www.trafik.gov.tr/Sayfalar/Istatistikler/Genel-Kaza. aspx (son erişim 25.05.2016)

4. http://www.resmigazete.gov.tr/eskiler/2013/03/20130330-4. htm (son erişim 25.05.2016)

5. http://www.resmigazete.gov.tr/eskiler/2013/08/20130803-6. htm (son erişim 25.05.2016)

6. http://www.tsb.org.tr/karayolu-yolcu-tasimaciligi-zorunlukoltuk-ferdi-kaza-sigortasi-genel-sartlari.aspx?pageID=503 (son erişim 25.05.2016) 